\title{
SPUTUM COLONIZATION BY Candida IN PATIENTS OF THE PNEUMOLOGY UNIT OF GENERAL HOSPITAL IN RECIFE (BRASIL). III. ${ }^{1}$
}

\author{
Colonización del esputo por Candida en pacientes de la unidad de \\ neumología de un hospital general en Recife. (Brasil). II.
}

Oliane M. C. Magalhaes, Lusinete A.de Queiroz, Cristina M. de Souza Departamento de Micologia, Centro de Ciências Biológicas, Universidade Federal de Pernambuco, 50670-420, Recife,

Palabras clave: Colonización, esputo, Candida

PE, Brasil.

Key word: Colonization, sputum, Candida

\section{RESUMEN}

Se pesquisaron 322 pacientes internados en la Unidad de neumologia del Hospital Geral Otovio de Freitas, Recife, PE, Brasil , para determinar la colonización por Candida en el esputo. De estos, 225 correspondian al sexo masculino y 97 al feminino. La colonización fue diagnosticada en 25 pacientes $(7,7 \%)$ del sexo masculino y $9(2,8 \%)$ del feminino. De los 25 casos detectados, 15 estaban asociados solamente a tuberculosis pulmonar, 5 a tuberculosis pulmonar y otra neumopatia, 2 a bronquiectasia, 1 a cancer pulmonar, 1 a fistula arteriovenosa y 1 a infección respiratoria.

Fueron aisladas 13 cepas de C. albicans, 6 C. parapsilosis, 4 C. membranaefaciens y 2 C. tropicalis.

\section{INTRODUCTION}

Candida is a genus of yeast with several species which have been found in saprophytism and in parasitism.

C. albicans, C. tropicalis, C. guilliermondii, $C$. parapsilosis, C. glabrata, are associated with superficial and deep mycoses (Loder, 1970; Connant et al., 1971; Rippon, 1982; Kreger-van-Rij, 1984; Lacaz et al., 1991).

Candidiasis is the most common mycotic infection in man and can strike any tissue, organ or system. Among the systematic candidiases, pulmonary, endocarditis, meningitis, renal, fungemia and other forms, can occur (Conant et al.; 1971; Rippon,1982; Wanke, 1984; Lacaz et al.; 1991).

Various authors have identified the presence of Candi$d a$ in patients with respiratory system problems, especially in pulmonary tuberculosis (Negroni \& Daglio, 1948; Scharting \& Skinner, 1948; Osoagbaka, 1981; Wanke, 1984; Kim et al., 1988; Lacaz et al., 1991; Kumar et al., 1992 ; Bandele et al., 1993) neoplasias (Salerno et al., 1986; Vidotto et al., 1986;

\section{SUMMARY}

Three hundred and twenty two patients hospitalized in the Pneumology Unit of the Otavio de Freitas General Hospital, Recife, PE, Brazil, were surveyed, being 225 males and 97 females. Amongst them Candida colonization was diagnosed in 25 (7.7\%), 16 (4.9\%) in male patient and 9 $(2.8 \%)$ in female ones. Of the 25 cases, 15 were associated only with pulmonary tuberculosis; 5 with pulmonary tuberculosis and another pneumopathy; 2 with bronchiectasis; 1 with pulmonarycancer; 1 with an arteriovenous fistula and 1 with respiratory infection.

Among the isolated strains, 13 were C. albicans, 6 C. parapsilosis, 4 C. membranaefaciens and 2 C. tropicalis.

Stokes et al., 1989; Pizzo \& Walsh, 1990; Winthorp et al., 1990; Grillot et al., 1991; Elias et al., 1993), as well as in patients with acquired immunodeficiency syndrome (Joshi et al.,1986; Lazarrin et el.,1987; Kyriais \& Kyriasis, 1993).

The objective of this study was to detect, isolated and identify fungi of the upper respiratory tract(sputum) in patients hospitalized in the Pneumology Unit of the Otavio de Freitas (SANCHO) General Hospital. Recife, Brasil.

\section{MATERIAL AND METHODS}

Sputum samples were collected from patients, hospitalized, with respiratory systems problems. Three hundred and twenty two patients were surveyed being 225 were male and 97 female.

The sputum samples were collected from each patient 3 times in sterilized Petri plates at intervals of 3 to 4 days. After collection, the samples were transported to the

1 Part of the dissertation for getting a Master's degree with support of Coordenaçao do Aperfeiçoamento de Nivel Superior (CAPES). 
Department of Mycology where they were duly processed for direct examination and culture. The time between collection and manipulation of those did not exceed 2 hours.

The direct examination of the sputum was carried out on their native state (without colouring and without clarifier) and clarified with aqueous solution at $20 \%$ of potassium hydroxide.

The sputum samples were seeded in duplicate, by spreading Sabouraud agar $+0.5 \%$ of yeast extract (YE) on their surface, to which $50 \mathrm{mg}$ of Chloramphenicol/1 contained in a Petri plate was added. A plate was left at room temperature $\left(28^{\circ} \mathrm{C} \pm 1^{\circ} \mathrm{C}\right)$ and the other incubated at $37^{\circ} \mathrm{C}$. The development of the cultures were lasted for up to 20 days.

The colonies which emerged after being purified were maintained in the above mentioned culture medium without antibiotic and held in a test tube.

To identify and classify the yeast strains Lodder, 1970; Kreger-van-Rij, 1984 and Barnet et al., 1990 methods were adopted.

The data about the patients were collected from their clinical records.

\section{RESULTS}

Candida colonization was diagnosed through the direct examination of the sputum of $25(7.7 \%)$ patients, being 16 (4.98) male and 9 (2.8\%) female. Direct examination revealed the presence of isolated yeast cells and pseudomycelium, both of which adhered to the epithelial cells present in the sputum (Figures 1 and 2).

In Sabouraud agar $+\mathrm{YE}+$ Chloramphenicol, both at room temperature $\left(28^{\circ} \mathrm{C} \pm 1^{\circ} \mathrm{C}\right)$ and at $37^{\circ} \mathrm{C}, 25$ Candida cultures were obtained, 13 were of $C$. albicans, $6 \mathrm{C}$. parapsilosis, 4 C. membranaefaciens and 2 C. tropicalis (Table 1).

C. albicans occurred in 7 male and 6 female patients; C. parapsilosis in 4 male and 2 female patients; $C$. membranaefaciens in 3 male and 1 female; $C$. tropicalis only in 2 male patients (Table 1; Figure 3).

The minimum age of the male patients was 29 and the maximum 85 years old. All of them had different occupations and all were born in the State of Pernambuco (Table 1).

The age of the female patients ranged from a minimum of 19 to a maximum of 78 years old, being all of them domestic servants. These patients were born in the State of Pernambuco; (Table 1).

Of the 16 male patients with colonization, C. albicans was isolated mainly in 5 patients with pulmonary tuberculosis and other species in another infections (Table 1)

Of the 9 cases of female patients with colonisation, $C$. albicans was isolated in 6 patients, mainly with pulmonary tuberculosis(3cases). (Table 1 ).

The strains of yeasts were stored in the MycothecaURM of the Biological Sciences Centre of the Federal
University of Pernambuco. Candida albicans under the N $(3622 ; 3623 ; 3625 ; 3626 ; 3628 ; 3629)$; Candida parapsilosis (3621; 3624; 3627); Candida membranaefaciens (3619) and Candida Tropicalis (3630).

\section{DISCUSSION}

Primary pulmonary candidiasis is rare, being more frequent the secondary attack of the lungs, because of various primary conditions such as tuberculosis and other bacterial and viral pneumopathies; neoplasias; suppurations; bronchiectasis and others (Wanke, 1984; Lacaz et al., 1991).

Due to the presence of Candida in such processes, its role is discussed in the quoted pneumopathies. Even as a secondary agent, this fungus can cause serious dangers (Lacaz et al., 1991).

In this study, the presence of Candida in the sputum, found in the direct examination and culture, was considered as "colonization" and not as candidiasis, based on considerations made by various authors. According to them, the presence of yeasts like Candida, Trichosporon and other opportunist fungi in the sputum, bronchial secretion or exudate, associated with other primary pathologies, is referred to by the terms colonization, secondary mycosis, opportunist pathogen and infection (Vidotto et al., 1986; Jain et al., 1991; Shigera et al., 1991; Kumar et al., 1992; Bandele et al., 1993).

The difficulties of diagnosing fo r pulmonary candidiasis are related to the clinical sample. What is considered of diagnostic value for primary pulmonary candidiasis is the demonstration of blastopores and/or pseudomycelium in samples obtained by pulmonary biopsy (Conant et al., 1971; Rippon, 1982; Browne et al., 1990; Pizzo \& Walsh, 1990; Lacaz et al., 1991).

It is worth emphasizing that the importance of the direct examination is unanswerable to give evidence of Candida in the sputum. This has also been emphasized by Negroni \& Daglio (1948); Schwarting \& Skinner (1948); Conant et al., (1971); Osoagbaka (1981); as well as Meunier (1990) and Remington (1990), when they refer to the presence of Candida in clinical samples of the buccal cavity.

The results of this study with sputum samples demonstrate Candida colonization in patients with different pneumopathies Taking into account men as well as women, the greatest number of cases occurred in patients in the age ranges of 32-49 and 72-78 years old (Table 1). Osoagbaka (1981) isolated the greatest number of Candida specimens from the sputum of patients with an age range of 41-80 years old without reference to sex.

Of 20 patients with pulmonary tuberculosis, there were 15 with BAAR positive, 1 with BAAR not undertaken and 4 with BAAR negative. Amongst them, 15 were carries of pulmonary tuberculosis only. The others presented different types of associations

Of patients who were not bearers of pulmonary 
Table 1.- Aspects related to the cases of Candida colonization detected in patients hospitalized.

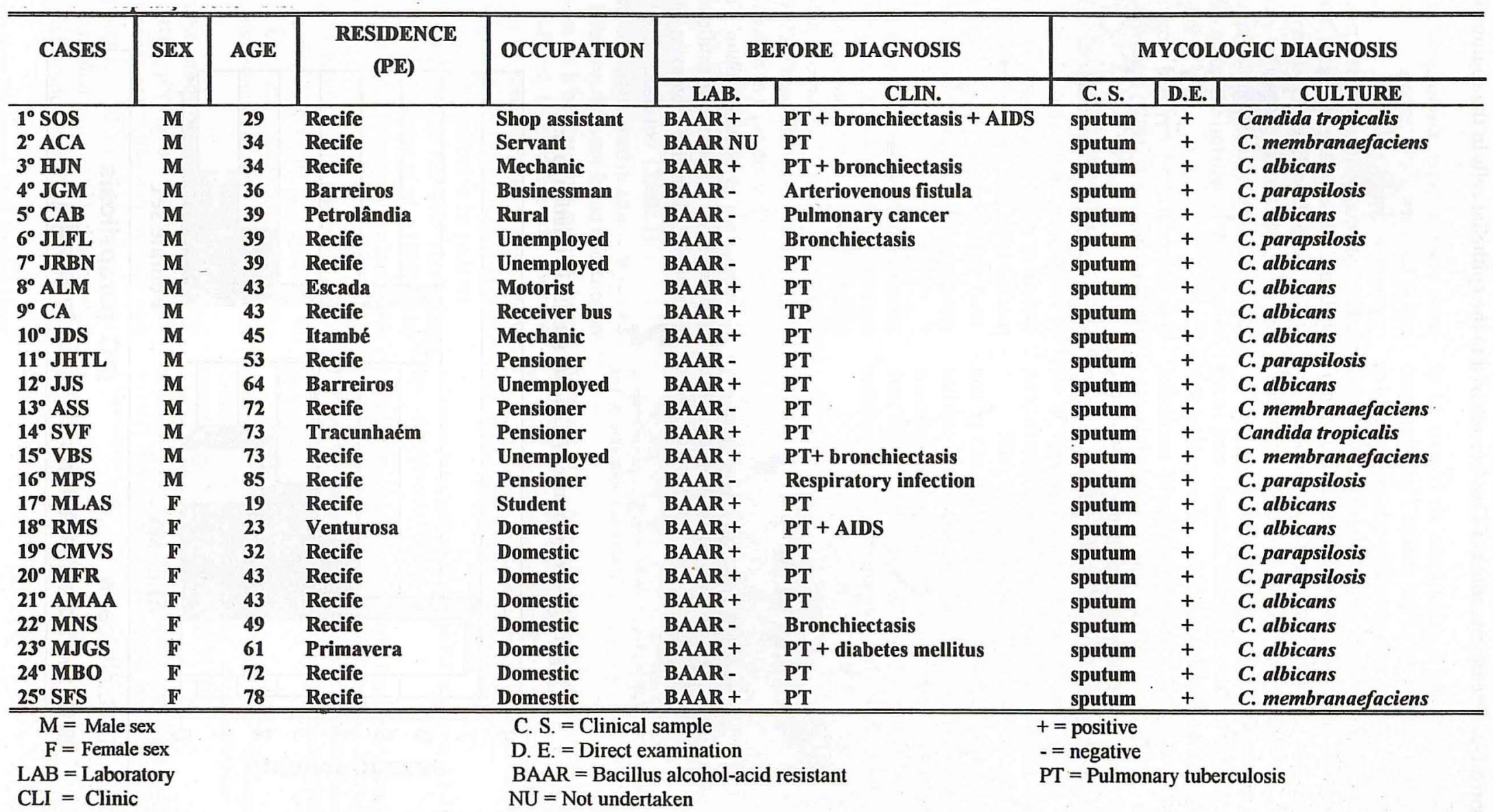


Figure 1-2.- Pseudomycelium of Candida adhered to the epithelial cells in the sputum $650 \mathrm{x}$.

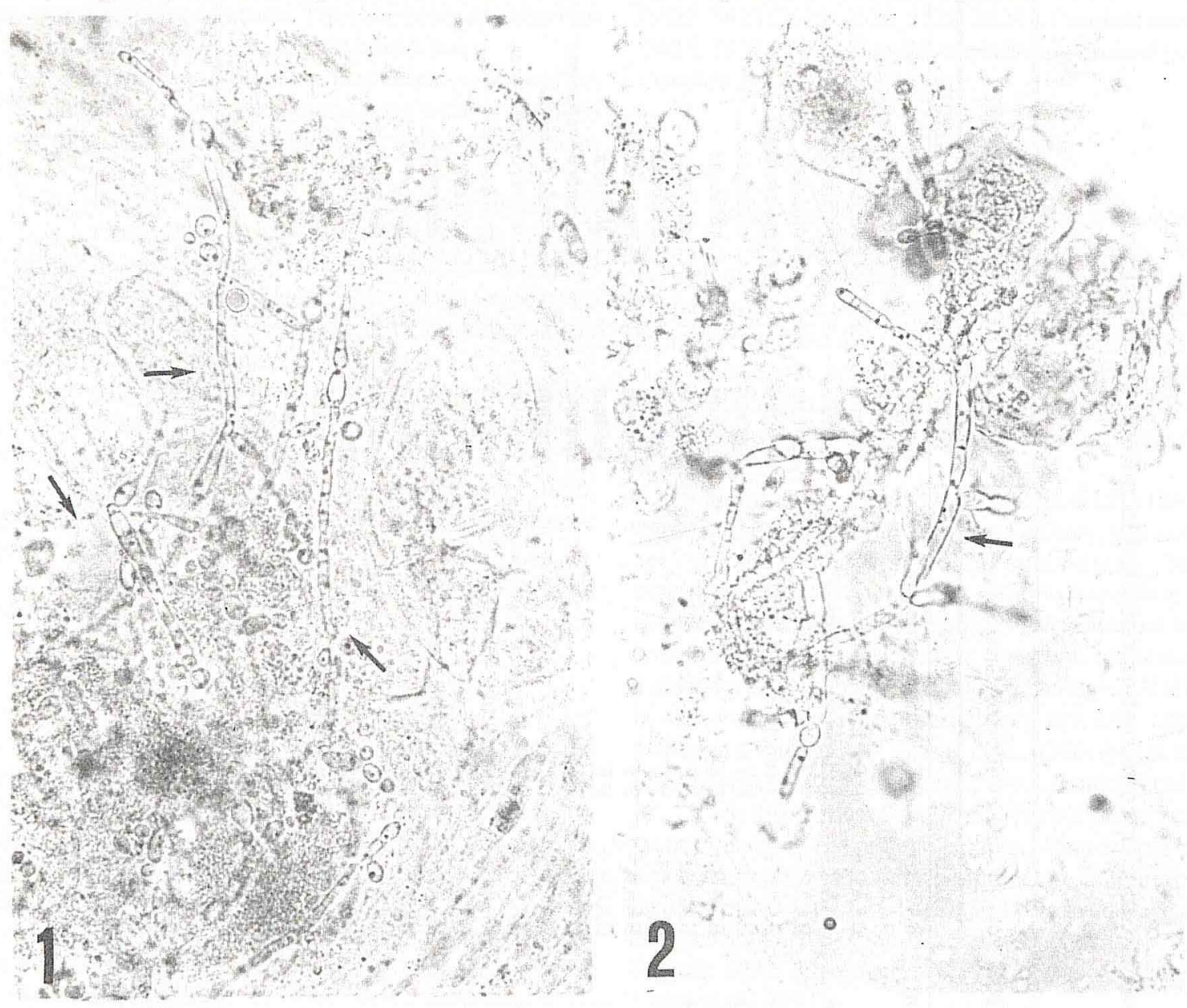

Figure 3. - Occurrence of Candida species in relation to sex.

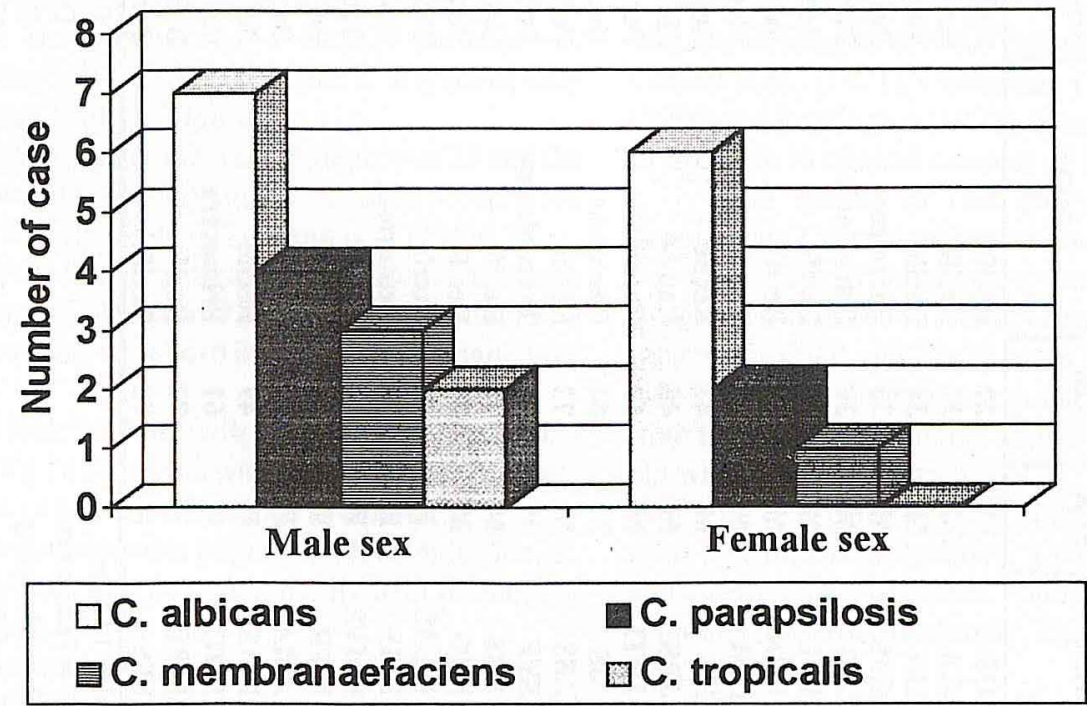


tuberculosis, the species $C$. parapsilosis and C.albicans were isolated. C. albicans was the species which occurred in the largest number of cases; on the other hand, pulmonary tuberculosis was the most prevalent pneumopathy. The presence of $\boldsymbol{C}$. albicans in these patients was also found by Osoagbaka (1981), Kumar et al. (1992), Bandele et al.(1993).

Patients with AIDS, represent a serious risk group for opportunist infections, amongst them those of a fungal nature. Lazzarin et al. (1987) also report the isolation of C. albicans in patients only with AIDS.

Cases of association between bronchiectasis and Candida are reported by Wanke (1984), Lacaz et al.(1991) and Kumar et al. (1992).

Patients with neoplasias under treatment present serious risks of infections, these are fungals which are difficult to diagnose and treat (Vidotto et al., 1986; Pizzo \& Walsh, 1990). Vidotto et al. (1986) apart from C. albicans isolated C. tropicalis, C. pseudotropicalis and C. glabrata (= Torulopsis glabrata) from patients with cancer in the respiratory tract.

The presence of Candida and Trichosporon in patients with cancer has been found through clinical samples obtained by brush, bronchial washing, exudation, biopsy and blood culture (Stokes et al., 1989; Browne et al., 1990; Shigehara et al., 1991; Elias et al., 1992). These last authors report a fatal case of septicemia by Candida in a patient with cancer.

The presence of Candida species in the sputum of patients with diabetes mellitus was reported by Bandele et al.(1993), as well as being reported in this study, however the patient had pulmonary tuberculosis too (Table 1).

Candida parapsilosis was isolated in an arteriovenous fistula and respiratory infection. Was not found reference on the isolation of this species with backgrounds such as these.

All the authors referred to in this study, mention pulmonary tuberculosis as the most frequent pneumopathy; this information is analagous to the results contained in Table 1 ; since the same pathology was reported in 20 patients.

The process of colonization by Candida, verified in this study, is corroborated by Nwobu et al. (1989), who isolated Candida strains from the sputum of patients with primary pneumopathy.

Bandele et al. (1993) did not consider the high percentage of pulmonary "infections" caused by species of Candida in patients with pulmonary tuberculosis due to the nutritional, depressive and immunological state of these patients.

An interest in infections by Candida has increased in recent years, due to the ageing population, those with cancer under treatment, with transplants, AIDS patients and with prolonged use of antibiotics and intensive care units. Colonization by species of Candida can evolve to a disseminated illness, mainly in immuno-compromised patients (Gibbs, 1990, Meunier, 1990).

Some gastroenterologists argue that unless these organisms are seen in biopsy, there is no reason why they have to be treated as candidiasis. This is incorrect, because esophagitis by Candida can be ulcerative, being it possible to have lesions also with a negative biopsy. On the other hand there can occur cases in which Candida invades the submucosa from where it enters the blood stream and is fully disseminated; consequently, the serious problem of oral and esophagal candidiasis is then evident (Remington, 1990).

Almost $50 \%$ of the patients with cancer die of infections from Candida, being the patients with altered immunological systems who demonstrate vulnerability to the infections. Diagnosing pneumonia by Candida without a pulmonary biopsy, but in autopsy, $61 \%$ of the patients with profound candidiasis presented pulmonary compromise. "This highlights the sad fact that nowadays we are not capable of making a diagnosis premortem in the majority of patients with deep candidiasis" (Remington, 1990).

Thus we can conclude that in all the cases of colonization by Candida, they were associated with pneumopathies and that mainly one species of yeast was isolated; $C$. albicans prevailed amongst the other species of the cases of colonization; it is worth emphasizing that direct examination is indispensable for the diagnosis of colonisation by Candida.

\section{REFERENCES}

1. Bandele, E. O.; Odubgemi, T.; Nwobv, R. A. V. (1993). Fungal chest infections at the Lagos University Teaching Hospital. East African Medical Journal. 70: 146-150

2. Barnett, J. A. ; Payne, R. W.; Yarrow, D. (1990). Yeasts. characteristics and identification. Cambridge University Press, Cambridge.

3. Browne, M. J.; Potter, D. ; Gress, J.; Cotton, D. ; Hiemenz, J. ; Thaler, N.; Hathorn, J. ; Brower, S. ; Gill, V.; Glatstein, E.; Pass, H.; Roth, J.; Wesley, R.; Shelhamer, J. \& Pizzo, P. (1990). A randomized trial of open lung biopsy versus empiric antimicrobial therapy in cancer patients with diffuse pulmonary in filtrates. J. Clin. Oncol. 8: 222-229

4. Conant, N.F.; Smith, D. T.; Baker, R. D.; Callaway, J. L. (1971) . Micologia, Interamericana, México.

5. Elias, A. D.; Ayash, L. ; Frei, E. III. ; Skarin, A. T.; Hunt, M.; Wheeler, C.; Schwartz, G. ; Mazanet, R. ; Tepler, I. ; Eder, J. P.; McCauley, M. ; Herman, T.; Schnipper, L.; Antman, K. H. (1993). Intensive combined modality therapy for limited-stage small cell lung cancer. J. Natl. Cancer Inst. 85: $559-566$

6. Gibbs, D. (1990). Programa Zoltec de Atualizaçao Cientifica: Candidiase orofaringea e outras infecçoes fúngicas em pacientes imunodeficientes. Copyright Laboratórios Pfizer.

7. Grillot, R. ; Lebean, B.; Pinel, C. ; Fricker, H.; Ambroise-Thomas, P. (1991). Biological diagnosis of systemic mycoses in patients with cancer. J. Mycol-Med. 4-10

8. Jain, S. K. ; Agrawal, R. L.; Pandey, R. C.; Agrawal, M.; Sharma, S. (1991). A clinic-radiological study of secondary mycoses in pulmonary tuberculosis. Indian. J. Med. Sci. 45: 81-84

9. Joshi, V. V.; Oleske, J. M.; Saad, S.; Connor, E. M.; Raplin, R. H.; 
Minnefor, A. B. (1986). Pathology of opportunistic infections in children with acquired immune deficiency syndrome. Pediatr. Pathol. 6: 145-150

10. Kim, S. J. ; Young, P. H. \& Sin, O. K. (1988). Fungal complications in patients with pulmonary tuberculosis or other diseases. Korean J. Mycol.16:2632.

11.Kreger - van Rij, N. J. W. (1984). The Yeasts: a taxonomic study. Elsevier Sci. Publi.Amsterdam.

12. Kumar, S. ; Kumar, R. ; Saini, S. ; Sobherwal, U.; Arora, D. R. (1992). Incidence of mycoses in bronchopulmonary disorders. Indian J. Pathol. Microbiol. 35: 237- 240

13. Kyriazis, A. P. \& Kyriasis, A. A. (1993). Incidence and distribution of opportunistic lung infection in AIDS patients related to intravenous drug use: a study of bronchoalveolar lavage cytology by the Diff-Quik stain. Diagn. Cytopathol. 9: 487-491

14. Lacaz, C. da S. ; Porto, E.; Martins, J. E. C.(1991). Micoloqia Médica fungos, actinomycetes e algas de interesse médico. Sarvier, Sao Paulo.

15. Lazzarin, A.; Orlando, G.; Privitera, G.; Crochiolo, P.; Esposito, R.; Foppa, C. U.; Castagna, A. ; Irato, L.; Moroni, M. (1987). Clinical and epidemiological aspects of the first 50 cases of AIDS in Milan [1:aly]. Boll. Inst. Sierotec. Milan. 65: 481-486

16. Lodder, J. (1970). The yeast: a taxonomic study. North Holland Publishing Company, Oxford.

17. Meunier, F. (1990). A epidemiologia da candidiase orofaringea: significado e doenpas subjacentes. Programa Zoltec de atualizaçao científica: candidiase orofaríngea e outras infecçoes fúngicas empacientes imunodeficientes. Copyright Laboratórios Pfizer.

18. Negroni, P. \& Daglio, C. A. N. (1948). Hongos blastosporados de los esputos. Mycol. et Mycopath. Appl. 4: 322-330

19. Nwobu, R. A.; Odugbem, T.; Eneje, R. C.;Bamidele, E. O. (1989). Mycologia and bacteriologic investigations of clinical sputum specimens in Lagos, Nigeria. West. Afr. J. Med. 8: 274-278
20. Osoagbaka, O. U. (1981). Aspergillus e Candida species isolates the sputa of patients with bronchopulmonary disorders in Nigeria. Mykosen. 24: 547-551

21. Pizzo, P. A. \& Walsh, T. J. (1990). Fungal infection in the pediatric cancer patient. Semin. Oncol. 17: 6-9

22. Remington, J. (1990). Susceptibilidade e resposta do hospedeiro em infecçoes fúngicas. Programa Zoltec de atualizaçao cientifica: candidiase e outras infeç̧oes em pacientes imunideficientes. Copyright Laboratórios Pfizer.

23. Rippon, J. W. (1982). Medical Mycology: the pathogenic fungi and the pathogenic actinomycetes. Copyright, Canada.

24. Salerno, R. A. ; Carvani, A. ; Ezcurra, M. C. ; Elias, A.; Tello, A. L.; Gomez, O.; Colombini, A. ; Klimovski, J.;Parise, A. (1986). Colonization and infection in leukemic patients: analysis of 195 surveillance cultures. Medicina (B. Aires) . 46: 369-376

25. Schwarting, V. M. \& Skinner, C. E. (1948). Candida in sputum of patients with tuberculosis. Mycopathologia . 4: 349-355

26. Shigehara, K.; Takahashi, K.; Tsunematsu, K.; Koba, H.; Katoh, S.; Asakawa, M.; Suzuki, A. (1991). A case of Trichosporon pullulans infection of the lung with adult T-cell leukemia. Jpm. J. Med. 30: 135-137

27. Stokes, D. C.; Shenep, J. L.; Parham, D. ; Bozeman, P. M.; Marienchek, W.; Mackert, P. W. (1989). Role of flexible bronchoscopy in the diagnosis of pulmonary infiltrates in pediatric patients with cancer. J. Pediatr. 115: $561-567$

28. Vidotto, V. ; Clerico, M. ; Franzin, L. ; Lucchini, L. ; Sinicco, A. (1986). Fungal colonization in patients with cancer of the upper respiratory tract. Mycopathologia. 96: 97-101

29. Wanke, B. (1984). Micoses pulmonares. Ars. Curandi. 71-82

30. Winthrop, A. L.; Waddell, T.; Superina, R. A. (1990). The diagnosis of pneumonia in the immunocompromised child: use of bronchoalveolar lavage. J. Pediatric. Surgery. 25: 878-880 